\title{
Community structure and regeneration pattern of Abies spectabilis in Sagarmatha National Park, Central Himalaya, Nepal
}

\begin{abstract}
A. B. Nagarkoti ${ }^{1}$, M. L. Pathak ${ }^{2 *}$, B. Pandey ${ }^{2}$ and A. Devkota ${ }^{1}$
Community structure and regeneration pattern of Abies spectabilis was studied along the elevation gradient from 2750 to $3550 \mathrm{~m}$ asl in mixed forest of $A$. spectabilis in Sagarmatha National Park, eastern Nepal. Various community attributes (viz. importance percentage, species diversity and beta diversity) and population characteristics (e. g. density- diameter, bar diagram) were analysed. Out of the thirtyfour species recorded from the study forest, $A$. spectabilis was the co-dominant species with high species diversity. Total tree density was the highest at $3450 \mathrm{~m}$ and the lowest at $3550 \mathrm{~m}$. Elevation appeared to be the important environmental factor that affects the community attributes of the study forest. The curve for $A$. spectabilis solely was slightly deviated from the typical reverse $\mathrm{J}$-shaped which indicates a discontinuous regeneration pattern. The distribution of the seedling and sapling distribution was not uniform. Seedling mortality was found relatively medium and development of seedlings into saplings was also low. The lower number of sapling might be due to moderate disturbance (grazing and trampling) by livestock or due to environmental factors. The use of Abies tree for construction and firewood might be the reason of unsustainability.
\end{abstract}

Key Words : Abies spectabilis, community structure, regeneration pattern, Sagarmatha National Park

$\mu$ bies, a genus under the family Pinaceace, is a large group of soft wood tree with 48 species in the world (Farjon, 2010). It is also called Himalayan silver fir (Vidakovic, 1991) while local people called 'Talispatra'. Abies are slow growing, tall evergreen, pyramidal tree that attains a height of $60 \mathrm{~m}$.

Its distribution in Nepal is restricted between the elevations of $2700 \mathrm{~m}$ and $3900 \mathrm{~m}$ above sea level (masl). The plants are found in moist open areas, woodland, garden, canopy zones. Three species are reported from Nepal viz. Abies spectabilis, A. densa, and A. pindrow (Anonymous, 2001; Hara et al., 1982; Press et al., 2000). The common associates of the $A$. spectabilis forests are Rhododendron, Betula, Acer and Sorbus species (Stainton, 1972).

Natural regeneration is a process in which the plant species replace themselves to maintain the ecosystem. It is the most important course of action for ensuring the replacement of any member of a community that dies off after completing life cycle (Fatubarin, 1987). Undisturbed forest with sustainable regeneration found to have a reverse J-shaped size-class distribution(West et al., 1981). A bell shaped size-class distribution has been attributed for disturbed forest where regeneration is hampered (Saxena et al., 1984). The issue of regeneration is mainly important for those forests which are under various anthropogenic pressures such as felling tree, grazing, trampling, etc (West et al., 1981). Counting of seedlings and saplings and analysis of size class distribution are methods for the regeneration analysis (Vetaas, 2000).

Regeneration of Abies was high as it can stand long winters and heavy snow, shade light, under low light and seedling can thrive under closed canopy of other species. It prefers a good moisture but not water-logged soil, grows well in heavy clay,

Central Department of Botany, Tribhuvan University, Kirtipur, Kathmandu,

2 Chengdu Institute of Biology, University of Chinese Academy of Sciences, Chengdu, Sichuan, China *E-mail : youngecologist@gmail.com 
acidic and neutral soil conditions (DPR, 2001). There are many similar attempts to study about the regeneration pattern of the different forest structure in the Himalaya (Ghimire and Lekhak, 2007; Kumar et al., 2004; Mehraj and Kumar, 2010; Shrestha et al., 2007; Tiwari, 2010).

A. spectabilis is the important timber and fuel wood tree in the temperate and sub- alpine area even up to the tree line. So, the demand of the Abies plant for construction and fuel wood, growth pattern, regeneration, impacts like grazing, trampling, etc. are being crucial concern for sustainable use of this preferred species.

The previous studies were focused mostly central and western Nepal (Acharya, 2004; Ghimire et al., 2008; Ghimire and Lekhak, 2007). Likewise, some studies reveal that the biomass distribution and tree invasion vary significantly with elevation (Fadrique et al., 2016). We have re- tested the hypothesis and have chosen some different locality to scrutinize new aspects of regeneration. Because the vegetation type, forest composition and climatic conditions are different in eastern, central and western Nepal (Stainton, 1972). In this context, the community structure of eastern Nepal with sustainability of $A$. spectabilis species is assessed in the designated field area which was situated along the trekking route of various tourist destinations in the foothills of the Himalayas. The study was focused only on narrow elevation zone due to technical hitches.

The general objective of the present study was to assess the vegetations of sub-alpine mixed $A$. spectabilis forest. The specific research questions that we tried to address were (i) What is the effect of altitude on community structure of sub-alpine mixed A. spectabilis forest in Sagarmatha National Park ? ( ii) What is the effect of environmental parameters like rock cover, soil carbon and elevation on regeneration of $A$. spectabilis ? (iii) How is the regeneration pattern of mixed $A$. spectabilis forest in study area?

The Park is managed by the Sagarmatha National Park Authority under the Department of National Parks and Wildlife Conservation, whereas, the buffer zone is managed by a Buffer Zone Management Committee (BZMC) within each village that takes care of location-specific issues by collaborating with the national park authority.
For this, the BZMC is an apex body under which different Buffer Zone User Committees (BZUCs) and Buffer Zone User Groups (BZUGs) have been formed and institutionalized in Sagarmatha National Park and its Buffer Zone (SNP, 2003). The distribution of fuel wood and necessary timbers from logging trees are also managed by BZUCs. There are no stringent rules to control grazing in the settlement of protected areas of Himalaya regions according to Himalayan National Park Regulations (HNPR, 1997) and practically it is not apposite too.

\section{Materials and methods}

\section{Study area}

The study was carried out in mixed forest of Abies spectabilis and Rododendron arboreum between Guranse Danda and Khumjung of the Sagarmatha National Park. The study area (Fig. 1) includes mainly Rhododendron and Abies forest along the trekking routes from Guranse Danda (2750 $\mathrm{m}$ asl), Gouyam (3040 $\mathrm{m}$ asl) to Lamjura (3500 $\mathrm{m}$ asl) and Khumjung (3550 $\mathrm{m}$ asl). The study was conducted on north-east facing slope with inclination of $35^{\circ}\left(27^{\circ} 30^{\prime}-50^{\prime} \mathrm{N}\right.$ and $86^{\circ} 40^{\prime}-$ $50^{\prime}$ E, elevation $2750-3550 \mathrm{~m}$ ).

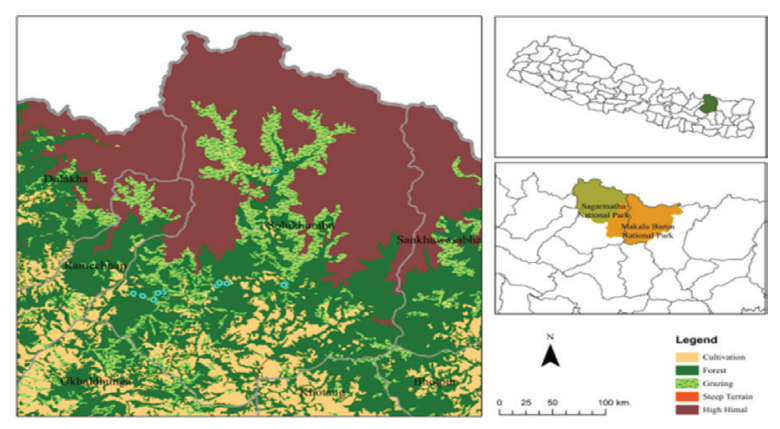

Fig. 1: Map of the study area

\section{Sampling methods}

Vegetation in the study area was sampled through systematic random sampling method (Vetaas, 2000). A total of 45 plots of 0.1 ha $\left(1000 \mathrm{~m}^{2}\right)$ were sampled between $2750 \mathrm{~m}$ to $3550 \mathrm{~m}$ each at $100 \mathrm{~m}$ elevation interval (Fig. 1). Nine vertical transects were defined within the study area and quadrats were located along each transect. Five sampling plots were laid in each elevation for one or both sides of the well-established footpath. The location for the first plot in each elevation was 
chosen on the side of the path where there was at least one mature Abies spectabilis tree. The distance between two transects were between 30-200 m. Other plots in the same elevation were laid at a distance of 30-200 m difference. The distance between the plots was determined on the basis of the accessibility and presence of $A$. spectabilis trees. If Abies trees were not observed along the sampling transect, a sidewise search was conducted on either side of the path at the same elevation.

The number of individuals of $A$. spestabilis at all life stages as tree, sapling and seedling were recorded and diameter at breast height (dbh) measured at $137 \mathrm{~cm}$ above the ground using dbh tape. All shrubs species present in the quadrat were recorded. Each tree species were grouped into tree $(\mathrm{dbh}>10 \mathrm{~cm})$, sapling $(\mathrm{dbh}<10 \mathrm{~cm}$, height $>30 \mathrm{~cm}$ ) and seedling (height $<30 \mathrm{~cm}$ ) (Sundriyal and Sharma, 1996). The predictor variables as slope, litter content, aspects, rock cover and land use pattern (tree lopping, logging, trampling evidences of human disturbances and cattle grazing) by visual estimation were also recorded to study the micro-environment. Lopping, logging and grazing were categorized as low, medium and high. Looping of 1-5 trees, 6-10 trees and more than 10 trees refers to low, meidum and high, respectively in each plot. Further low is coded as 1, medium as 2 and high as 3 . Similar scale was used for logging and grazing. Grazing pattern was categorized based on the number of piles of cattle dung present within the plots. We did a general discussion among the key stakeholders regarding the consumption of fire wood in different season of the year.

From each quadrat, $200 \mathrm{~g}$ soil sample was collected from the corners and centre of each quadrat at a depth of $30 \mathrm{~cm}$ and their physiochemical characteristics (Soil pH, Carbon and Nitrogen content) were analysed. Relative radiation index
(RRI) was calculated from the values of aspect $(\Omega)$, slope $(\beta)$ and latitude $(\Phi)$. The value ranges from +1 to -1 . RRI was calculated following the formula given by Oke (1987) :

$R R I=\operatorname{Cos}(180-\Omega) \cdot \operatorname{Sin}(\Phi)+\operatorname{Cos} \beta \cdot \operatorname{Cos} \Phi$

Various community attributes like importance percentage, species diversity, beta diversity and population characteristics (e. g. density- diameter bar diagram) were analysed (Shannon and Warner, 1949; Simpson, 1949). Ordination methods were used to analyse species composition and to relate this to rock cover, soil carbon and elevation using "Vegan" package in R (Oksanen, 2015). Detrended corresponding analysis (DCA) was used to analyse sparse data matrices. DCA is a multivariate stastistical technique widely used by ecologist to find the main factors or gradients in large, species rich but usually sparse data matrices that typify ecological data. Ordination of the different characters and elevation on two axis DCA 1 and DCA 2 are evaluated and explained in our study (Table 1).

\section{Results and discussion}

\section{Results \\ Species composition}

While observing species composition, Daphne bholua, Tsuga dumosa, Berberis aristata dominated in elevation between between $2750-3150$ $\mathrm{m}$ asl while Abies spectabilis, Rhododendron arboreum, Quercus semicarpifolia and Juniperus indica dominated between $3150-3550 \mathrm{~m}$ asl, Rhododendron, Juniperus etc. were the associated species of Abies Altogether thirty four species of trees and shrubs were recorded, of which, twelve species were tree while remaining were sapling. However, A. spectabilis, Q. semicarpifolia and Pinus wallichina reached to canopy layer. Remaining species were confined only to sub-canopy layer.

Table 1 : Summary of DCA result

\begin{tabular}{|l|l|l|l|}
\hline Axis & Eigenvalues & Decorana values & Axis lengths \\
\hline DCA1 & 0.4666 & 0.4797 & 3.6192 \\
\hline DCA2 & 0.1932 & 0.2341 & 2.3670 \\
\hline DCA3 & 0.2083 & 0.1549 & 2.3504 \\
\hline DCA4 & 0.14325 & 0.09719 & 1.95503 \\
\hline Sum of Eigen value & 1.011 & & \\
\hline
\end{tabular}


Table 2: Frequency (F), Relative Frequency (RF), Density (D), Relative Density (RD), Basal Cover (BC), Relative Basal cover (RBC) and Importance Percentage (IP) of tree species in mixed Abies spectabilis forest of the study area

\begin{tabular}{|c|c|c|c|c|c|c|c|c|}
\hline S. N. & Plant Name & $\mathbf{F}(\%)$ & RF (\%) & \begin{tabular}{|l|} 
D (stem// \\
ha)
\end{tabular} & $\begin{array}{l}\text { RD } \\
(\%)\end{array}$ & BC (\%) & \begin{tabular}{|l|} 
RBC \\
$(\%)$
\end{tabular} & \begin{tabular}{|l|} 
IP \\
$(\%)$
\end{tabular} \\
\hline 1 & Rhododendron arboreum $\mathrm{Sm}$. & 100 & 42.86 & 184.88 & 79.26 & 1589.46 & 63.63 & 61.91 \\
\hline 2 & Abies spectabilis (D. Don.) Mirb. & 60 & 25.71 & 60.88 & 11.9 & 763.66 & 30.57 & 22.72 \\
\hline 3 & Michelia champaca L. & 2.22 & 0.95 & 0.44 & 0.18 & 20.29 & 0.81 & 0.64 \\
\hline 4 & Lyonia ovalifolia (Wall.) Drude & 4.44 & 1.9 & 0.44 & 0.18 & 2.64 & 0.10 & 0.72 \\
\hline 5 & Quercus semicarpifolia $\mathrm{Sm}$. & 17.77 & 7.61 & 10.22 & 4.38 & 77.38 & 3.09 & 5.02 \\
\hline 6 & Eurya acuminate DC. & 8.88 & 3.8 & 1.11 & 0.47 & 7.58 & 0.30 & 1.5 \\
\hline 7 & Betula utilis D. Don. & 6.66 & 2.85 & 1.5 & 0.64 & 5.44 & 0.21 & 1.2 \\
\hline 8 & Prunus cornuta (Wall. Ex Royle) & 11.11 & 4.76 & 1.77 & 0.75 & 8.57 & 0.34 & 1.95 \\
\hline 9 & Juniperus indica Bertol & 15.55 & 6.66 & 4.22 & 1.81 & 15.72 & 0.62 & 3.03 \\
\hline 10 & Tsuga dumosa (D. Don) Eichler & 2.22 & 0.95 & 0.22 & 0.09 & 1.57 & 0.06 & 0.36 \\
\hline 11 & Acer sp. & 2.22 & 0.95 & 0.22 & 0.09 & 1.18 & 0.04 & 0.36 \\
\hline 12 & Salix sp. & 2.22 & 0.95 & 0.44 & 0.18 & 4.22 & 0.16 & 0.43 \\
\hline Total & & 233.29 & 99.95 & 266.34 & 99.93 & 2497.71 & 99.93 & 99.84 \\
\hline
\end{tabular}

Twenty two species were recorded in Shrub layer and mainly dominated by D. bholua, B. aristata, Lonicera lanceolata at lower altitude whereas higher altitude was dominated by Juniperus species and some of places by Vibrurnum species. D. bholua was the most frequently occurring $(53.3 \%)$.

The diversity dominance curve showed that out of twelve species, five species had IP less than $1 \%$ (Table 2).

The total number of woody species (trees and shrubs) recorded was 34. Among trees, Rhododendron arboreum had the highest IP (61. 91\%) and then after A. spectabilis had 22. 72\% IP (Table 2). Average species richness for tree was found to be 130 species/ha and shrub species richness was 108 species/ha. Beta diversity for tree was 1.26. Simpson's index of dominance (C) for tree was 0. 44 and Shannon-Wiener index (H') of species diversity was 1.21 . The sapling and tree ratio was lowest for $A$. spectabilis than the seedling and tree ratio and seedling and sapling ratio.

The total tree density of various species was found to be $267.11 \mathrm{stems} / \mathrm{ha}$ and the density of seedlings and saplings of A. spectabilis were 76. 89 and 28 . 44 stems/ha respectively whereas total sapling and seedling density were 1086 and 524.2 stems/ha (Table 3).
The mean tree canopy cover was $53.78 \%$ while the distribution pattern of seedling and sapling of Abies was not uniform, however, $40 \%$ of the studied sub-plots were with seedlings while 66 . $67 \%$ of studied were without sapling and $40 \%$ of plot had no A. spectabilis trees. Total sapling density increased with altitude up to $3050 \mathrm{~m}$ after that it decreased up to $3350 \mathrm{~m}$. Total seedling density of all tree species was lower than that of sapling density (Fig. 2), which was not a normal demographic development. The most densely populated plots were found between $3450 \mathrm{~m}$ and $3550 \mathrm{~m}$. Total basal area of tree species was 2.24 $\mathrm{m}^{2} /$ ha. In the highest elevation range, trees were small with lower basal area. The highest basal area of Abies tree was found at $3450 \mathrm{~m}\left(6.033 \mathrm{~m}^{2} / \mathrm{ha}\right)$.

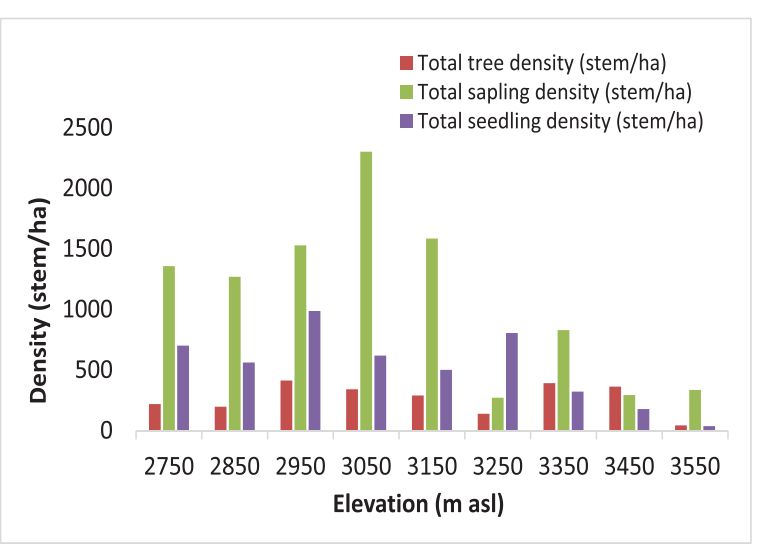

Fig. 2: Density of all species along elevation gradient 
Intensity of grazing/trampling was relatively high in the study forest (Table 3). Soil of the forest under study was slightly acidic in nature with $\mathrm{pH}$ ranging from 4.2 to 5.93 . Total carbon content in soil varied between $1.24 \%$ to $6.79 \%$ and nitrogen content in the soil was found between $0.11 \%$ and $0.52 \%$ (Table $3)$.

Table 3 : Descriptive statistics of all the variables used

\begin{tabular}{|c|c|c|c|c|c|c|c|}
\hline Variables (Unit) & Mean & Minimum & Maximum & SE & SD & Kurtosis & Skewness \\
\hline $\begin{array}{l}\text { Total Tree Density } \\
(\text { Stem } / h a)\end{array}$ & 267.11 & 10 & 570 & 23.59 & 158.22 & -1.05 & 0.10 \\
\hline $\begin{array}{l}\text { Total Sapling Density } \\
(\text { Stem } / \mathrm{ha})\end{array}$ & 1086.44 & 70 & 3300 & 112.33 & 753.54 & -0.05 & 0.59 \\
\hline $\begin{array}{l}\text { Total Seedling Density } \\
(\text { Stem/ha) }\end{array}$ & 524.22 & 20 & 2230 & 80.30 & 538.65 & 2.79 & 1.69 \\
\hline $\begin{array}{l}\text { Total Tree Basal Area } \\
\left(\mathrm{m}^{2}\right)\end{array}$ & 2.24 & 0.173 & 6.033 & 0.24 & 1.58 & -0.66 & 0.58 \\
\hline $\begin{array}{l}\text { Abies Seedling Density } \\
(\text { Stem } / \mathrm{ha})\end{array}$ & 76.89 & 0 & 910 & 29.05 & 194.90 & 10.63 & 3.29 \\
\hline $\begin{array}{l}\text { Abies Sapling Density } \\
(\text { Stem } / \mathrm{ha})\end{array}$ & 28.44 & 0 & 250 & 8.60 & 57.68 & 4.94 & 2.30 \\
\hline Elevation (m) & 3150.00 & 2750 & 3550 & 38.92 & 261.12 & -1.23 & 0.00 \\
\hline $\begin{array}{l}\text { Total Species Richness } \\
(\text { Count })\end{array}$ & 5.29 & 1 & 16 & 0.50 & 3.33 & 0.64 & 0.75 \\
\hline Tree (Count) & 6.09 & 0 & 31 & 1.19 & 7.97 & 2.45 & 1.64 \\
\hline Sapling (Count) & 2.84 & 0 & 25 & 0.86 & 5.77 & 4.94 & 2.30 \\
\hline Seedling $($ Count $)$ & 7.89 & 0 & 91 & 2.90 & 19.46 & 10.58 & 3.27 \\
\hline $\mathrm{pH}$ & 5.17 & 4.2 & 5.93 & 0.06 & 0.39 & 0.34 & -0.29 \\
\hline Soil Carbon content (\%) & 3.06 & 1.246 & 6.792 & 0.21 & 1.40 & -0.19 & 0.59 \\
\hline $\begin{array}{l}\text { Soil Nitrogen content } \\
(\%)\end{array}$ & 0.27 & 0.112 & 0.518 & 0.01 & 0.09 & 0.54 & 0.72 \\
\hline Lopping (categorical) & 1.11 & 1 & 2 & 0.05 & 0.32 & 4.77 & 2.56 \\
\hline Logging (categorical) & 1.42 & 1 & 3 & 0.09 & 0.62 & 0.45 & 1.20 \\
\hline Grazing (categorical) & 1.29 & 1 & 2 & 0.07 & 0.46 & -1.12 & 0.96 \\
\hline Slope $\left(^{\circ}\right)$ & 186.56 & 90 & 280 & 8.91 & 59.76 & -1.16 & 0.09 \\
\hline Aspect $\left(^{\circ}\right)$ & 34.58 & 10 & 45 & 1.30 & 8.72 & 0.25 & -0.89 \\
\hline Litter $(\%)$ & 2.16 & 1 & 3.8 & 0.09 & 0.58 & 0.18 & 0.51 \\
\hline Canopy (\%) & 53.78 & 5 & 80 & 3.10 & 20.81 & -0.18 & -0.78 \\
\hline Rock Cover (\%) & 16.44 & 0 & 80 & 2.73 & 18.33 & 3.22 & 1.80 \\
\hline $\begin{array}{l}\text { Relative Refractive } \\
\text { Index }\end{array}$ & 0.02 & -0.90 & 0.98 & 0.09 & 0.62 & -1.37 & 0.13 \\
\hline
\end{tabular}


Relation of the different community attributes with environmental variables The environmental parameters such as rock cover, soil carbon and elevation were fitted in this ordination diagram (Fig. 3).

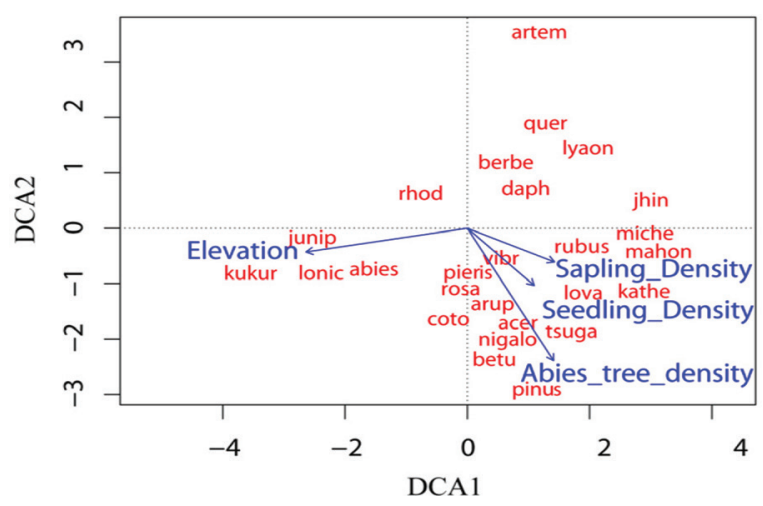

Fig. 3: Ordination diagram obtained by Detrended Correspondence Analyses (DCA)

Density of all species along with elevation (Fig. 2) and importance percentage of the Abies is shown (Fig. 4).

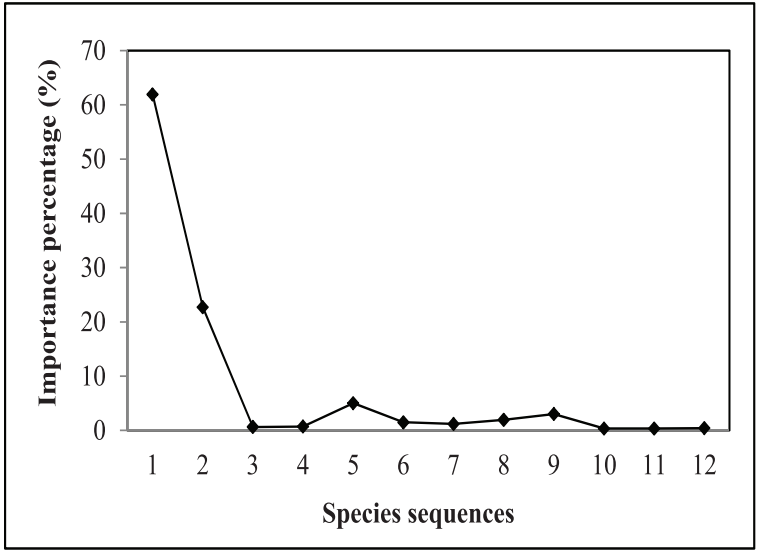

Fig. 4: Diversity-dominance curve for the tree species of the mixed Abies spectabilis forest

The bi-plot diagram of species and elevation showed that elevation had strong correlation with respect to distribution of various species along axis I. The total seedling density decreases with increased elevation.

The relation of the different community attributes with environmental variables is explained (Fig. 5-14).

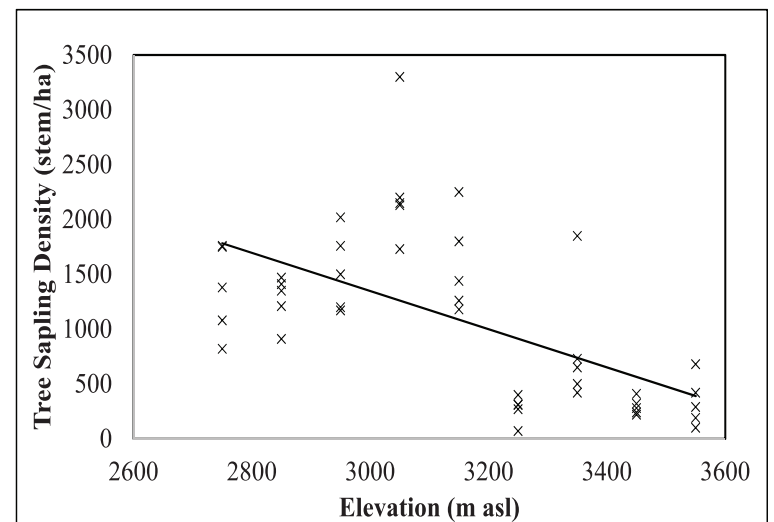

Fig. 5: Total Sapling density along with elevation gradient

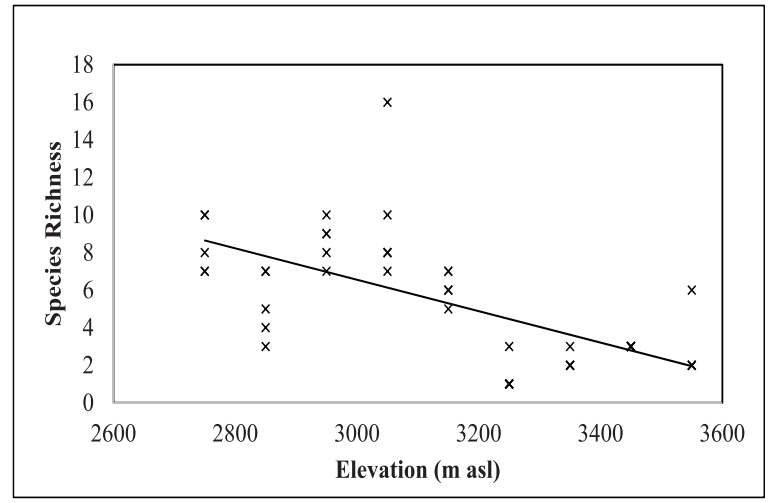

Fig. 6: Species richness along with elevation gradient

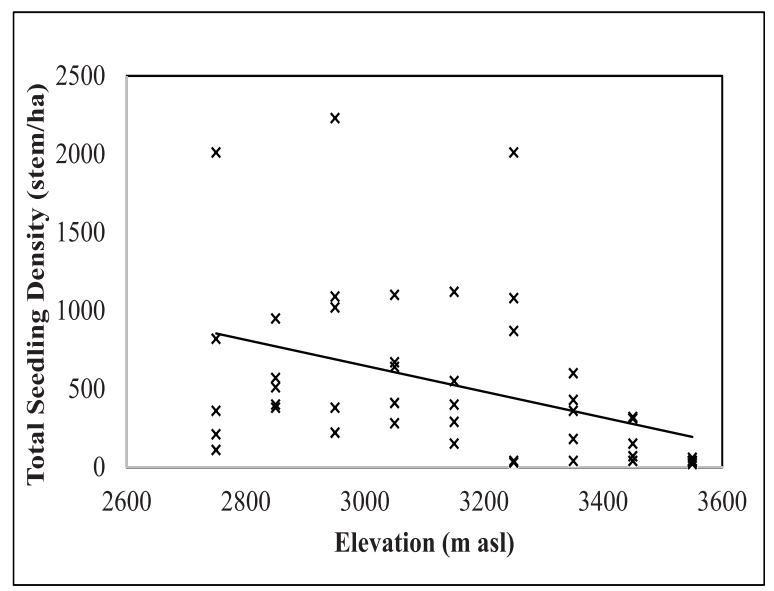

Fig. 7: Seedling densities of Abies along with elevation 


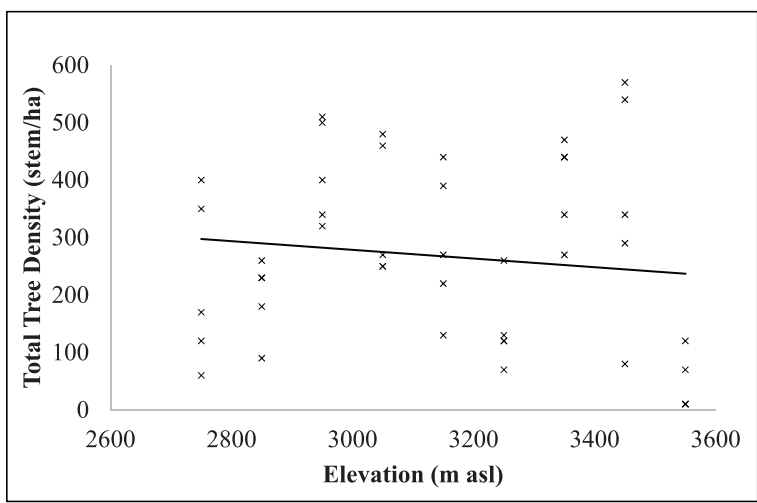

Fig. 8: Total tree density along with elevation

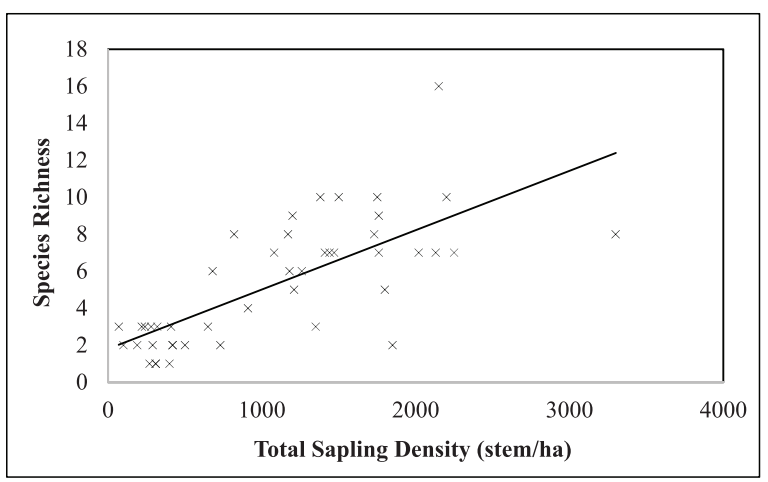

Fig. 9: Relationship between species richness and total sapling density

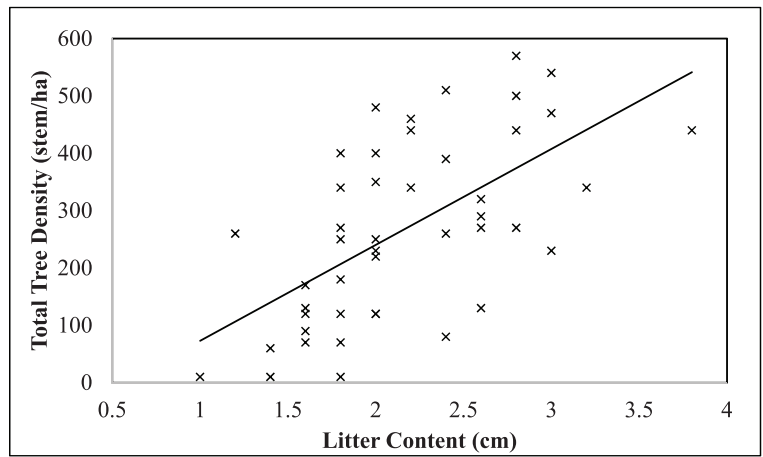

Fig. 10: Relationship between total tree density and litter content

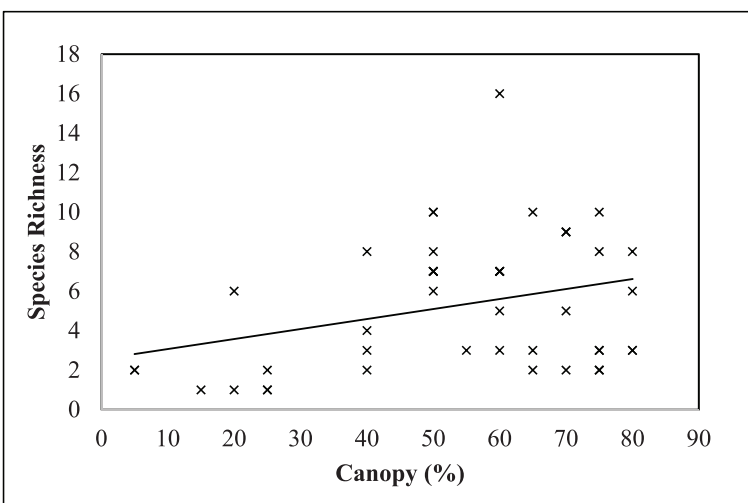

Fig. 11: Species richness of Abies tree along with canopy

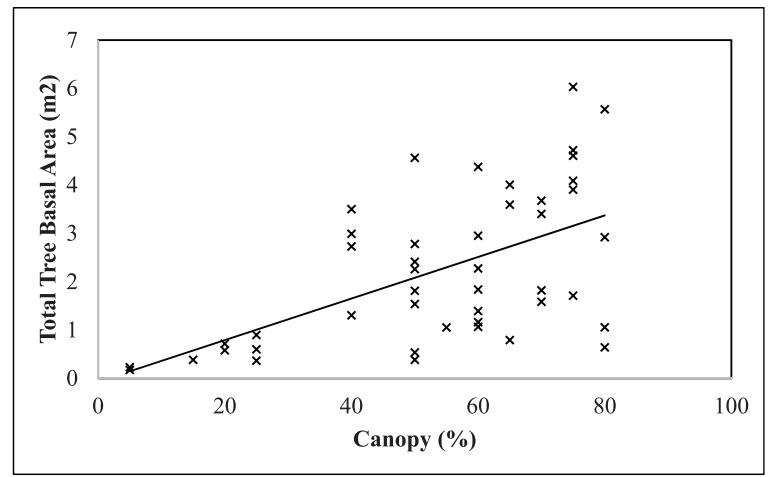

Fig. 12: Total tree basal area vs canopy (\%)

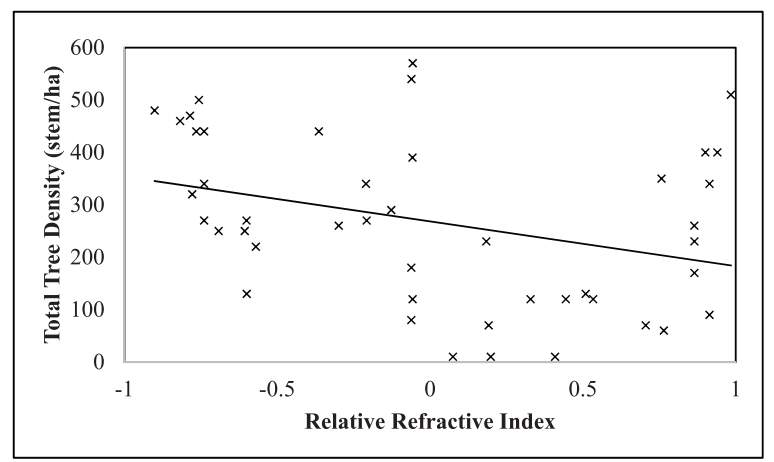

Fig. 13: Total tree density vs Relative Refractive Index 


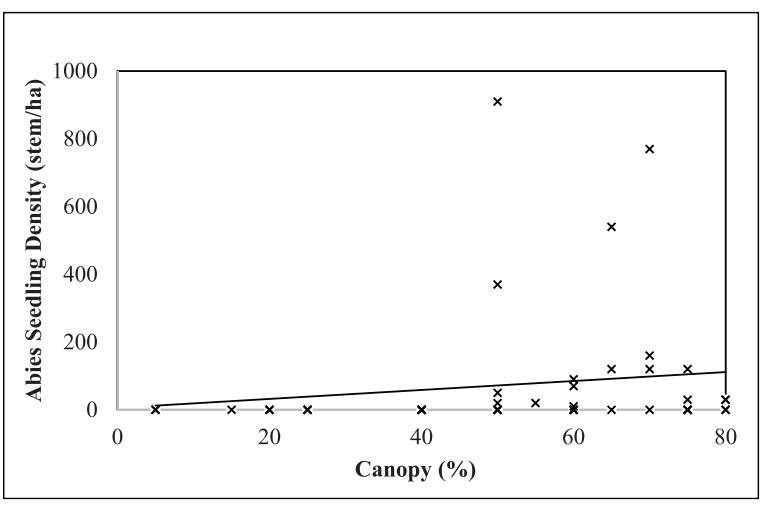

Fig 14: Seedling density of Abies spectabilis vs canopy (\%)

Elevation appeared to be the important environmental factor that affected the community attributes of the study forest. The total sapling density, seedling density of Abies and total density of trees decreased along with elevation. Seedling density, population of Abies tree and total basal area were increased along with the canopy (Figs. 11, 12 and 14). Total tree density increased with litter content but decreased with relative refractive index.

Density of seedlings of $A$. spectabilis declined with increasing height classes. There was gradual decline in density from first to last height class (Fig. 14). Density-diameter curve for all tree species combined was nearly reverse J-shaped indicating continuous regeneration (Fig. 15). Also it was observed that medium girth trees were used by people mainly for construction and firewood.

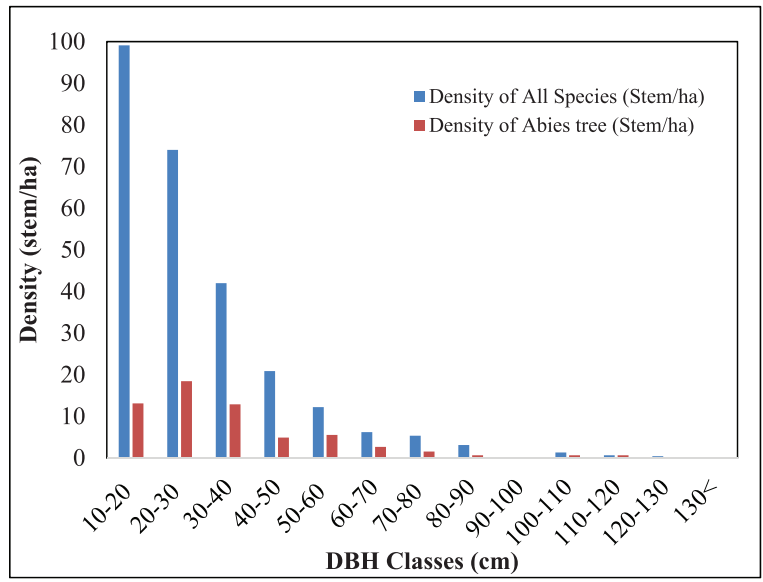

Fig. 15: Density-diameter curve for Abies spectabilis alone as well as all tree species of the forest
Correlation test was done among population density and environmental variables to evaluate the relationship of various variables with species richness. Summary of environmental correlation matrix among the explanatory variables are shown (Annex-1). There was a highly significant correlation $(r=0.73)$ between the total sapling vs. species richness, sapling population of Abies vs. Abies seedling density, seedling population of Abies vs. Abies sapling density, seedling population vs. tree population of Abies and canopy cover $v s$. total tree density. Seedling population of $A$. spectabilis showed significant positive correlation with the tree population $(r=0.73)$ and saplings of Abies $(r=0.37)$. The number of seedlings was higher where the trees and saplings were high. Species richness $(\mathrm{r}=$ -0.66), total sapling density $(r=-0.6)$ and total seedling density $(r=-0.4)$ showed negatively significant correlation with elevation. Similarly total tree density $(r=0.61)$, total tree basal area $(r=0.47)$ and number of Abies trees $(r=0.41)$ were significant with litter content in soil. Species richness $(r=0.32)$, total tree density $(r=0.73)$ and total basal area $(r=0.57)$ were positively significant correlation with canopy cover of trees. The summary of DCA results showed that axis-I have a high Eigen value (0.46) and was correlated with elevation (Table 1 ). The degree of divergence and heterogeneity increased with the elevation as indicated by the length of the gradients of the DCA axis-I and their Eigen values (Table 1).

\section{Discussion}

The average tree density showed that the number decreases along with elevation within the range of study area which is also similar to the observation (Shrestha et al., 2007) in the trans- Himalayan tree line and in Eastern Himalayan (Bhuju et al. 2010). In upper Manang mixed forest, it was found that the total tree density ranged from 375 plants/ha at altitude $3800-4000 \mathrm{~m}$ to 845 plants/ ha at 3300-3500 m. In mixed A. spectabilis forest of Manang, the total tree density was found 900 stem/ha (Acharya, 2004). Whereas total tree density was found 1274 stem/ha in sub alpine $A$. mariesii forest of central Japan (Mori and Takeda 2005) and 759 stem/ha in sub-alpine coniferous forest on Changbai Mountain, China (Qi- Jing, 1997). Tree density (267.1 stem/ha) in present study was lower than tree density $445 \mathrm{stem} / \mathrm{ha}$ (Bhuju et al., 2010) from tree line of Sagarmatha 
National Park. Lower value of total tree density in the study site might be due to logging and high disturbance due to grazing and trampling. Also, the study area was near to trekking route so it might be the impact of tourism. In general discussion with local people, it was found that the rate of consumption of fire wood was high during the winter season and months of September to November which is the most favourable time for visitors. It was also visualized that the use of Abies as timber tree was common in hotel area than other regions.

In the present study, tree density of $A$. spectabilis was found less (76.89 stems/ha) than previous studies (Acharya, 2004; Scholl and Taylor, 2006). This showed that the study forest was not pure $A$. spectabilis forest and co dominant by observing.

Density-diameter curve for all tree species combined was nearly reverse J-shaped, indicating sustainable regeneration. But, the curve of $A$. spectabilis alone deviated slightly from the typical reverse J-shape. Reverse J- shaped densitydiameter curve is the indication of unsustainable regeneration (Vetaas, 2000). Similar trend was reported by (Acharya, 2004; Shrestha et al., 2007; Ghimire et al., 2008; Qiaoying et al., 2008). Some observation (Bhuju et al., 2010) found bell shaped diameter class distribution of $A$. spectabilis and inversed $\mathrm{J}$ shaped distribution of $B$. utilis at tree line (Eastern Nepal). The same study recorded $99 \mathrm{~cm} \mathrm{DBH}$ of $A$. spectabilis whereas the highest DBH of A. spectabilis was $120 \mathrm{~cm}$ in present study. The result indicated that density of the trees having larger girth size was higher than that of the smaller girth size in whole mixed A. spectabilis forest. A. spectabilis curve slightly fluctuated from the typical reverse J-shape which did not indicate sustainable regeneration of co-dominant species A. spectabilis. However, sustainability of whole forest might be of further research interest.

Lower sapling density (28. 44 stems/ha) in the present forest might be due to higher seedling mortality because of several disturbances. Mechanical damage to seedlings of $A$. spectabilis due to intense grazing and trampling may lead to high seedling mortality. Seedling density of Abies also declined with increasing canopy (Fig. 14). Seedling generally preferred high soil moisture, moderate $\mathrm{pH}$ and moderate canopy cover. As A. spectabilis is shade tolerant species it can regenerate under a densely closed canopy (Qi-Jing, 1997). High frequency of saplings of A. spectabilis under dense canopy has been also inferred in mixed Betula utilis-A. spectabilis forest of Manang (Shrestha et al., 2007). However, in the present study, frequency $(28.89 \%)$ of saplings was very low, and it was absent in homogeneity stands. The seedling and sapling ratio shows higher proportion of sapling than seedling in A. spectabilis for which sapling is higher than seedling indicating recent regeneration. There was significant influence of grazing on tree seedling species composition (Darabant et al., 2007). Intensity of grazing and trampling was relatively medium (2.26 out of 3 ) in the studied forest.

The study area was also slightly acidic in nature with $\mathrm{pH}$ ranging from 4.2 to 5.93. Most conifer foliage contains acid substances and after decomposition of leaves it will keep soil slightly acidic or neutral. The $\mathrm{pH}$ range of 5.5 to 6.5 may provide most satisfactory plant nutrient and is most suitable for most plants (Brady and Well, 1984). Similar results were found in the alpine forest of central Nepal (Ghimire and Lekhak 2007; Shrestha et al., 2007; Tiwari 2010) and Garhwal Himalaya, India (Kumar et al., 2004; Mehraj et al., 2010). Both soil organic carbon (OC) and nitrogen (N) content $(3.06 \%$ and $0.27 \%$ respectively) in the present study forest were relatively low. This might be due to wide spacing of trees which provide low input litter cover to the soil $(2.16 \mathrm{~cm})$.

The study forest can be considered as the mixed forest. The previous similar study on A. pindrow has shown as dominant species (Importants Percentage $=16.44 \%$ ) and Betula utilis as codominant species $(\mathrm{IP}=16.10 \%)$ in north-western slope of mixed Abies-Betula forest of Indian Himalaya (Gairola et al., 2008). However, we found $A$. spectabilis as co-dominent species after Rhododendron arboreum (With IP 22.72\% and $61.91 \%$, respectively).

The trend of average total basal area of study area showed similarities with previous studies, (Qi-Jing 1997; Scholl and Taylor 2006; Bhuju et al. 2010). Average Beta diversity ( $\beta$ ), Simpson's Index of Dominance $(C)$ for tree and ShannonWiener Index ( $\left.\mathrm{H}^{\prime}\right)$ of species diversity was $1.26,0.44$ and 1.21 respectively in the present 
study forest. The result was compared with previous studies (Liyun et al., 2006; Ghimire et al., 2008; Jiangming et al., 2008; Sharma et al., 2009; Tiwari, 2010) where, species diversity in forest edge was higher than that in pure forest which was possibly caused by 'edge effect'. This is the effect that changes in population or community structures that occur at the boundary of two habitats. Species richness usually reduces along the vertical gradient and it is caused by the decrease of temperature (Qi-Jing, 1997).

The higher seedling and sapling distribution found were $910 \mathrm{stems} / \mathrm{ha}$ and $250 \mathrm{stems} / \mathrm{ha}$ at 3050 and $2950 \mathrm{~m}$, respectively. In the previous studies (West $e t$ al., 1981; Acharya, 2004; Diaci et al., 2005; Ghimire and Lekhak 2007; Tiwari 2010), the seedling density of Abies was found higher than that of sapling density which shows a normal demographic development. The differences in different attributes of Abies tree might be due to various geological circumstances, mostly temperature, rainfall and clamminess of study sites which we have considered here unvarying while comparing.

\section{Conclusions}

Abies spectabilis was the co-dominant species among trees after Rhododendron arboreum tree. The seedling density was higher than that of sapling density which shows a normal demographic development. Density-diameter curve for all tree species combined was nearly reverse J-shaped, indicating sustainable regeneration. But density-diameter curve for A. spectabilis was not continuous which did not show sustainable regeneration. So that the cutting of timber to build house and for firewood should be controlled by concerned Authority, Grazing pressure should be minimised at AprilMay during the period of seedling development and human pressure should be controlled. The BZUCs and BZUGs should be categorized as the forests and land use for conservation, community use and for grazing under the rules of the National Parks and Wildlife Conservation Act (NPWCA, 1973), the Himalayan National Park Regulations (HNPR, 1979) and the Buffer Zone Management Guidelines (BZMG, 1999) the community user groups should make the local people aware for sustainable use of forest products which can provide the legal basis for protection of the flora and fauna as well.

\section{References}

Acharya, K. P. 2004. Post Fire Natural Regeneration of Dominant Tree Species in Pisang, Manang, Nepal. M. Sc. dissertation. Tribhuvan University. Central Department of Botany, Kirtipur, Kathmandu.

Bhuju, D. R., Carrer, M., Gaire, N. P., Soraruf, L., Riondato, R., Salerno, F. and Maharjan, S. R. 2010. Dendroecological study of high altitude forest at Sagarmatha National Park. In Contemporary Research in Sagarmatha (Mt. Everest) Region, Nepal : An Anthology (eds). Jha, P. K. and Khanal, I. P., Nepal Academy of Science and Technology, Lalitpur, Nepal, pp 119-130.

Brady, N. C. and Well, R. R. 1984. The Nature and Properties of Soils. Mac Millan Press. New York, USA.

BZMG 1999. Buffer Zone Management Guideline. Government of Nepal. Ministry of Forests and Soil Conservation, Singhdurbar, Kathmandu, Nepal.

Darabant, A., Rai, P. B., Tenzin, K., Roder, W. Gratzer, G. 2007. Cattle grazing facilitate tree regeneration in a conifer forest with palatable bamboo understorey. Forest Ecology and Management 252: 73 - 83. https ://doi. org/10. 1016/j. foreco. 2007. 06. 018.

Diaci, J., Pisek, R. Boncina, A. 2005. Regeneration in experimental gaps of subalpine Picea abies forest in the Slovenian Alps. European Journal of Forest Research 124: 29 - 36. https ://doi. org/10. 1007/s10342005-0057-7.

DPR, 2001. Flowering Plants of Nepal. In Bulletin of Department of Plant Resources. No. 18. Kathmandu, Nepal.

Fadrique, B., Homeier, J. and Woods, K. 2016. Elevation and topography influence community structure, biomass and host tree interaction of Lianas in tropical montane forests of southern Ecuador, Journal of Vegetation Science 27 :958 - 968. https :// doi. org/10. 1111/jvs. 12427 
Farjon, A. 2010. A Handbook of the World's Conifers. Leiden, Netherlands : Brill Academic Publishers.

Fatubarin, A. 1987. Observation on the natural regeneration of the woody plants in a Savana ecosystem in Nigeria. Tropical Ecology 28: $1-8$.

Gairola, S., Rawal, R. S. and Todari, N. P. 2008. Forest Vegetation patterns along an altitudinal gradient in sub-alpine zone of west Himalaya, India. African Journal of Plant Science 2, 42 - 48.

Ghimire, B. K. and Lekhak, H. D. 2007. Regeneration of Abies spectabilis (D. Don) Mirb. in subalpine forest of Upper Manang, North central Nepal, in : Chaudhary, R. P., Aase, T. H., Veetas, O. R., Subedi, B. P. (Eds.) Local Effects of Global Changes in the Himalayas : Manang, Nepal. Tribhuvan University, Nepal and University of Bergen, Norway, pp 139 - 149.

Ghimire, B. K., Lekhak, H. D., Chaudhary, R. P. and Vetaas, O. R. 2008. Vegetation Analysis along an altitudinal gradient of Juniperus indica forest in southern Manang Valley, Nepal. International Journal of Ecology and Development 9: 20 - 29.

Hara, H., Charter, A. O. Wiliams, L. H. J. 1982. An Enumeration of the Flowering Plants of Nepal, Vol. 3, British Museum (Natural History), London, U. K.

HNPR. 1979. Himalayan National Park Rules. Nepal Law Commission, Government of Nepal.

Jiangming, M. A., Liu, S., Shi, Z., Zhang, Y., Kang, B. and Chen, B. 2008. Changes in Species composition and diversity in the restoration process of sub alpine dark brown coniferous forest in west Sichuan Province, China. Frontiers of Biology in China 3: 300-307. https ://doi. org/10. 1007/s11461-008-0047-2

Kumar, M., Sharma, C. M. and Rajwar, G. S. 2004. A study on the community structure and diversity of a sub-tropical forest of
Garhwal Himalayas. Indian Forester 130, $207-214$.

Liyun, M., Xiaoan, W. and Zhigao, W. 2006. Studies on species diversity of Larix chinensis community ecotone. Frontiers of Biology in China 2: 163 - 167. https ://doi. org/10. 1007/s11515-006-005-2

Mehraj, A. S. and Kumar, M., 2010. Nutrient Status and Economic Analysis of Soils in Oak and Pine Forests in Garhwal Himalaya. Journal of American Science 6: 117-122.

Mori, A. and Takeda, H. 2005. Changes in shoot properties in relation to vertical positions within the crown of mature canopy trees of Abiesmariesii and Abiesveitchii. Journal of Forest Research 10: 51-55. https ://doi. org/10. 1007/s10310-004-0095-x

NPWCA. and 1973. National Parks and Wildlife Conservation Act. Government of Nepal. Ministry of Forests and Soil Conservation Singha Durbar, Kathmandu, Nepal.

Olke, J. 2015. Vegan : an introduction to ordination. URL http ://cran. r-project. org/ web/packages/vegan/vignettes/introvegan. Pdf, 8: 19.

Press, J. R., Shrestha, K. K. and Sutton, D. A. 2000. An annotated checklist of the flowering plants of Nepal. London : British Museum (Natural History) and Kathmandu : Central Department of Botany, Tribhuvan University.

Qiaoying, Z., Peng, L. and Yunchun, Z. 2008. Ecological characteristics of Abies georgei population at timberline on the north facing slope of Baima Snow Mountain, Southwest China. Acta Ecological Sinica 28: 129-135. https ://doi. org/10. 1016/ S1872-2032 (08)60022-0

Qi-Jing, L. 1997. Structure and dynamics of the subalpine coniferous forest on Changbai Mountain, China. Plant Ecology 132: 97-105.

Saxena, A. K., Singh, S. P., Singh and J. S. 1984. Population structure of forests of Kumaun 
Himalaya : Implications for management. Journal of Environmental Management 19: 307-324.

Scholl, A. E. and Taylor, A. H. 2006. Regeneration patterns in old-growth red fir - western white pine forests in the northern Sierra Nevada, Lake Tahoe, USA. Forest Ecology and Management 235, 143-154. https :// doi. org/10. 1016/j. foreco. 2006. 08. 006

Shannon, C. E. and Wiener, W. 1949. The Mathematical Theory of Communication. University of Illinois Press, Urbana, USA.

Sharma, C. M., Sarvvsh, S., Gairola, S. and Ghildiyal, S. K. 2009. Species richness and diversity along an altitudinal gradient in moist temperate forest of Garhwal Himalaya. Journal of American Science 5: 119-128.

Shrestha, B. B., Ghimire, B. K., Lekhak, H. D. and Jha, P. K. 2007. Regeneration of tree line birch (Betula utilis D. Don) forest in a transHimalayan dry valley in Central Nepal. Mountain Research and Development 27: 259-267. https ://doi. org/10. 1659/mrdd. 0784

Simpson, E. H. 1949. Measurement of diversity. Nature 163: 688. http ://dx. doi. org/10. 1038/163688a0

SNP. 2003. Sagarmatha National Park Buffer Zone Management Plan 2003-2007. Sagarmatha National Park office, Namche Bazaar, Solukhumbu, Nepal.
Stainton, J. D. A. 1972. Forest of Nepal. John Murray Publishers, Ltd. London, UK.

Sundriyal, R. C. and Sharma, D. 1996. Anthropogenic pressure on tree structure and biomass in the temperate forest of Mamlay watershed in Sikkim. Forest Ecology and Management 81: 113-134.

Tiwari, R. M. 2010. Comunity Structure and Regeneration of Sub-alpine Abies spectabilis (D. Don). Mirb. Forest of Langtang National Park, Central Nepal. M. Sc. Thesis. Tribhuvan University, Kirtipur, Kathmandu, Nepal

Vetaas, O. R. 2000. The effect of environmental factors on the regeneration of Quercus semecarpifolia Sm. in Central Himalayan, Nepal. Plant Ecology 146: 137-144. https ://doi. org/10. 1023/A :1009860227886

Vidaković, M. 1991. Conifers : morphology and variation. Grafičko Zavod Hrvatske. Zagreb, YugoslaviaI.

West, D. C., Shugart, H. H. and Ranney, J. W. 1981. Population structure of forests over a large area. Forest Science 27: 701-710. 


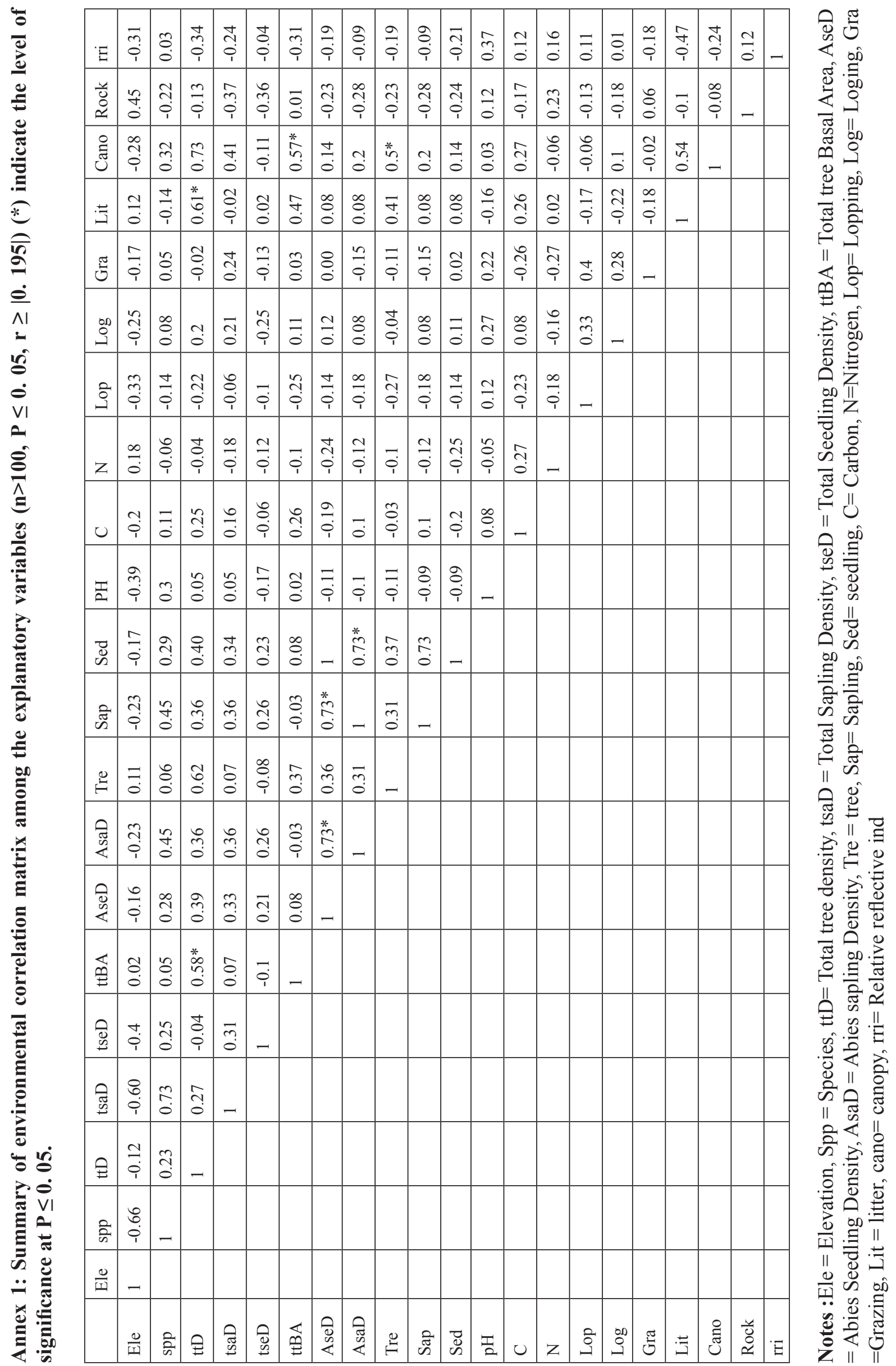

